\title{
The Impact of the General Level of Prices and Operating Profit on Economic Value Added (EVA) (Analytical Study: ASE 2001 - 2015)
}

\author{
Ebraheem Al Taha'at ${ }^{1}$, Mohammad Abdel Mohsen Al-Afeef ${ }^{2}$, \& Saqer Al Tahat ${ }^{3}$ \& Muhannad Akram Ahmad ${ }^{3}$ \\ ${ }^{1}$ Faculty of Agriculture, Jerash University, Jerash, Jordan \\ ${ }^{2}$ Faculty of Economics and Administrative Sciences, Jerash University, Jordan \\ ${ }^{3}$ Department of Accounting, Faculty of Economics and Administrative Sciences, Al al-Bayt University, Mafraq \\ Jordan \\ Correspondence: Mohammad Abdel Mohsen Al-Afeef. E-mail: afeif500@yahoo.com
}

Received: September 21, 2017

Accepted: October 11, 2017 Online Published: October 28, 2017

doi:10.5539/ass.v13n11p142

URL: https://doi.org/10.5539/ass.v13n11p142

\begin{abstract}
This study aims to show the importance of the economic value added as one of the most modern to measure the financial performance for firms, then to know the effect of the general prices level and earnings before interest and taxes on EVA in the companies listed in (ASE) (2006-2015), the researcher addresses a random sample consisting of (46) Company, and uses regression model, which connects the dependent and independent variables.

The results of the study shows that There is a significant impact for the general prices level and the earnings before interest and taxes on the economic value added, and also shows that $22 \%$ of the changes in the economic value added are due to general prices level and earnings before interest and taxes, and $78 \%$ of the changes are due to other factors.

This study also recommends the need to manage of operating expenses because of the positive impact of operating profit on EVA value, and to take inflation into account when calculating the value of EVA, and also searching for other factors that could affect the value of EVA such as sales volume, cost of capital, and the growth in the total assets of the company's financial leverage, etc...
\end{abstract}

Keywords: Economic Value Added, general prices level, earnings before interest, Jordanian Companies, Amman Stock Exchange

\section{Introduction}

Economic value added (EVA) is one of the most important measure of a company's financial performance. The goal of EVA is to quantify the cost for investing capital into a certain project, and then assess whether it is generating enough cash to be considered a good investment. EVA Basically, used to measure the value of the company generated from the invested funds. If EVA is negative, it means the company is not generating value from the funds invested into the business. But if EVA positive, it means that a company is producing value from funds invested (Chen and Dodd, 1997).

The purpose of EVA is to assess company and management performance. EVA champions the idea a business is only profitable when it creates wealth and returns for shareholders, and requires performance above a company's cost of capital.

There are three key components to a company's EVA: NOPAT, the amount of capital invested, and the WACC. NOPAT can be calculated manually but normally by using earnings before interest and tax which is listed in a public company's income statements. Capital invested is the amount of money used to finance project. WACC is the weighted average cost of capital, it derived as a fraction of each financial source in a company's capital structure (Chen and Dodd, 1997).

EVA as a performance indicator is very useful. The calculation shows how and where a company created wealth, through the inclusion of balance sheet items. This forces managers to be aware of assets and expenses when making managerial decisions. However, the EVA calculation relies heavily on some factors, so this study had been focused on two factors that may affect EAV measure. These factors are general prices level and earnings 
before interest and tax (Shil, 2009)

\subsection{Problem}

Because of the importance of the economic value added as one of the traditional standards in measuring the financial performance of companies, researchers trying to find the effect of each of the general price level and earnings before interest and taxes on the economic added value in the Jordanian companies listed on Amman Stock Exchange for the period (2001-2015). The study reflected the problem by answering the following questions:

1) Is there an effect of the general price level on the economic value added in Jordanian companies listed on Amman Stock Exchange for the period (2001-2015).

2) Is there an effect of the earnings before interest and taxes on the economic value added in Jordanian companies listed on Amman Stock Exchange for the period (2001-2015).

\subsection{Importance}

The importance of this study came from the importance of economic sectors in promotion renaissance and strength the national economy; especially Jordanian companies listed on Amman Stock Exchange. Also, this study was important in drawing the attention of managers of those companies to economic value added (EVA) as one of the most important performance used to measure the financial performance of the companies, and helps them to achieve maximization the wealth of owners.

The importance also came from knowing the factors may effect (EVA), specially general price level (GPL) and operating profit (OP), to adopt a more advanced approach to improve financial performance, including proper planning helps to achieve strategic goals, foremost of which is to maximize the market value of the shares, and to maximize the wealth of shareholders.

\subsection{Objectives}

The aims of the study were:

3) To show the importance of the economic value added as one of the most modern to measure the financial performance for firms.

4) To know some of factors may be effecting the economic value added.

5) To know of the effect of the general prices level on the economic value added.

6) To know the effect of earnings before interest and taxes at the expense of economic value added.

\section{Literature Review}

\subsection{Economic value added (EVA).}

EVA is the economic value added, it is one of the most important economic and accounting standards. "EVA can be used for the purposes of setting organizational goals, performance measurement, determining bonus, communication with shareholders and investors, motivation of managers, capital budgeting, corporate budgeting, corporate valuation, etc".( Awan AG, Siddique K, Sarwar G, 2014).

The concept of value-added popularized in the classical economic thought, however, that the current interest in this concept goes back to the US consulting firm Stern \& Stewart, where they performance a new model of the performance evaluation in the last century (Al-Sharqawi, 2006).

Economic added value defined by Stern Stewart as a measure of financial achievement to estimate the real profit, which is linked to the wealth of shareholders over time, which is the difference between the adjusted net operating profit after taxes and weighted cost of capital WACC (Jiambalov, 2007) (Al-Afeef, 2017).

The economic value added is general index to measure the external performance of the firms, including guarantees for investors more returns on their investments, and reflect the cumulative measure of the returns for the shareholder in capital, which reflects the quality of administrative decisions of financial and operational in the companies in the long term, because the positive value reflected on maximizing the wealth of owners, every company making a profit is a profitable company, but not every company making a profit is able to create value (Shil, 2009), (Falateh \& Al-Khayal, 2009).

According to senior vice president of Stern Stewart \& Co in one of his studies, that among all performance metrics used no more accurate than the economic value added, as the companies that use them as an indicator and the framework for financial management significantly outperformed their counterparts in the competition. All measurement methods that are used by companies to measure their performance (Ehrbar, 1998) (Al-Afeef, 
2017).

As for the method of calculating the (EVA) there are many ways to do that, but of the main methods used to measure the (EVA) is net operating profit after taxes (NOPAT) minus firm's capital multiplied by Weighted Average Cost of Capital (WACC). The researchers will adopt this method to calculate (EVA) by equations no (1). (Ismail, 2011) (Al-Afeef, 2017).

$$
\mathrm{EVAt}=\mathrm{NOPAT}-\mathrm{Ct} * \mathrm{WACC}
$$

Whereas:

EVA: Economic Value Added

NOPAT: Net operating profit after tax.

Ct: firm's capital.

WACC: weighted average cost of capital

\subsection{Earnings before interest and taxes (EBIT)}

EBIT is a measure of a firms net sales excluded all operating expenses which is; (cost of goods, selling -general and administrative expenses, research and development, and depreciation) all before interest and tax.

Or EBIT is an entity's profitability that excludes interest and income tax expenses. The reason that interest rate and taxes are excluded because it is not related to operating expenses. EBIT also called operating profit shows an entity's earning power from ongoing operations (Swaminathan \& Weintrop, 1991).

EBIT can be calculated by equations 2 and 3 as the name implies, which is:

$$
\begin{gathered}
E B I T=\text { gross income }- \text { operating expenses } \\
E B I T=\text { Net profit }- \text { interest expense }- \text { income tax expense }
\end{gathered}
$$

The researchers adopted the previous two equations to calculate EBIT

Why EBIT?

In this study EBIT is very important factor to calculate net operating profit after tax (NOPAT) which is used for the calculation of an economic value added (EVA).

NOPAT the amount of cash earnings left over taxes have been paid for the year. In other words, it is a company's potential cash earnings if its capitalization were unleveraged that is, if it had no debt.

Why NOPAT Matters? NOPAT uses only operating income, income before interest payments and taxes. So, NOPAT gives a clearer view for operating efficiency, and how companies got financial leveraged was able to get. This is important, because of the interest payments on debt reduce net income and also reduce the company's tax expense. Simply NOPAT looks at how company's core operations did, net of taxes.

There are two ways in equations 4 and 5 to calculate NOPAT

$$
\begin{aligned}
& \text { NOPAT = Operating Income } x(1-\text { Tax Rate }) \\
& \text { NOPAT }=\text { Net Income }+ \text { Net Interest Expense } x(1-\text { Tax Rate })
\end{aligned}
$$

The researchers adopted the equations no. (4) to calculating NOPAT.

\subsection{General Price level (GPL)}

General Price level (GPL) is an index that measures the change in price of goods in an economy over time and hence the purchasing power of the currency of the country. If all prices stay fixed for a while, the price level is unchanged, too. When inflation takes place, the price level arises (McCulloch, 1982).

The general price level is measured by a price index. A price index is a weighted average of the prices of a selected basket of goods and services relative to their prices in some base-year (Patell, 1978).

To construct a price index we start by selecting a base year. Then we take a representative sample of goods and services and calculate their value in the base year and current prices. The ratio of the expenditures on the basket of goods at current prices to the expenditure at the base year prices is taken as the price index (Tippett and Whittington, 2012).

The researchers will adopt this method to calculate the Price Index for period (t) by equation no. (6) (Mohammad, 2009). 


$$
\text { Price Index for period }(t)=\frac{\text { Market Basket for the period }(t)}{\text { Market Basket for the period }(t-1)} X 100
$$

\subsection{Previous studies}

There were a theoretical discussed the general theory behind EVA. For example, The study of Al-Afeef, 2017) try to test and find the impact of EVA and ROI on the change in Stock market's value in the companies listed in (ASE) (2006-2015), the study shows that the (ROI) is better than (EVA) to explain the changes in Stock market's value, where the study recommends the need to look for additional factors that would explain the changes in stock market's value.

The study of (Hassan, 2014) which reported that (EVA) offers a consistent approach towards setting goals and measuring performance. This paper employed EVA on Pakistani listed commercial banks to validate the claim of Stewart as EVA to be a strong performance indicator. In this regard, an attempt has been made for examining relationship between market value added, economic value added, return on equity, return on capital employed, price-to-earnings ratio, and market to book value, with the consideration that EVA is the significant indicator of shareholder value creation in relation to other traditional accounting measures. The result showed positive correlation of EVA with MVA (Market Value Added).

Hundal S., (2015), examined the association between the Economic Value Added (EVA) and the firm decision making and performance, and the interplay between the EVA and various dynamics of agency costs. The researcher find the essence of the EVA was that true profit does not arise merely by paying debt cost to firms' debt holders but only when shareholders were also rewarded with a fair return on their investment. The EVA raises the bar of corporate performance, which adds value to the firm, and determines performance based executive pay; consequently, mitigating agency costs. Nonetheless, several institutional factors restrict applicability of the EVA.

A paper for (Sharma and Kumar, 2010) presented a comprehensive literature review and a critical analysis to move towards the advances in EVA. It may be a very useful source of information to the researchers and managers who wish to understand and implement EVA and carry out further research on the diverse issues of this interesting and value adding performance metric, he finds that The studies conducted in the developed countries have largely been found to be supporting EVA though there are certain studies in these countries too that consider conventional measures as better tools of corporate performance reporting. However, in developing economies less numbers of studies are available supporting the empirical validity of the concept as a corporate performance measurement tool. The concept of EVA has gained significant attention in the advanced economies, but implementation issues and its validity is under debate all over the world. In a paper for (Shil,2009), an earnest effort has been made to explain theoretical foundation of EVA with its origination, definition, ways to make it tailored, adjustments required, scope and some other related issues. The methodology used is a type of theoretical mining of logics resulting a step-by-step process required for EVA implementation. As corporate house plans to move from traditional to value based performance measures, EVA would yield good result and the paper may become helpful to them to comprehend the methodology. A paper for (Anil and Kanwal, 2007), aimed to find out whether EVA finds a better reflection in the firms' stock prices. If it does then EVA would emerge as the better measure of financial performance compared to the traditional accounting based measures. The hypothesis of this study was that of the seven chosen independent variables. EVA is the single most significant explanatory variable in explaining the variation in the Market Value Added as it finds a better reflection in the market value of the share. The above hypothesis was tested on the time series data of 'A group' companies listed on the Bombay Stock Exchange. The period of the study was 5 years beginning from the FY 2002-03 and ending with FY 2006-07. Cross sectional analysis of the sample firms has been done using the tool of Regression Analysis. Another study for (Worthington and West, 2004), Pooled time-series, cross-sectional data on 110 Australian companies over the period 1992- 1998 was employed to examine whether the trademarked variant of residual income known as economic value-added (EVA) was more highly associated with stock returns than other commonly-used accounting-based measures. These other measures of internal and external performance include earnings, net cash flow and residual income. Three alternative formulations for pooling data were also employed in the analysis, namely, the common effects, fixed effects and random effects models, with the fixed effects approach found to be the most empirically appropriate. Relative information content tests revealed returns to be more closely associated with EVA than residual income, earnings and net cash flow, respectively. An analysis of the components of EVA confirms that the GAAP-related adjustments most closely associated with EVA were significant at the margin in explaining stock returns. (Chen and Dodd, 1997), this study examined the 
EVA performance of 566 U.S. companies and compares the information usefulness of EVA with accounting earnings and residual income. The result was, although improving EVA performance was associated with a higher stock return, the association was not as perfect as claimed by EVA advocates. EVA was more powerful than traditional measures of accounting profit in explaining stock return; however, accounting earnings were still of significant incremental information value in addition to EVA, and not only is EVA similar to residual income in concept, the two metrics were empirically comparable. The implications of the findings for researchers and practitioners were discussed.

Table 1. Summary of the results of related researches

\begin{tabular}{|c|c|c|}
\hline $\begin{array}{c}\text { Researcher and Research } \\
\text { Year }\end{array}$ & Variable & Result \\
\hline $\begin{array}{l}\text { Al-Afeef, } \quad 2017, \quad \text { ASE: } \\
\text { 2006-2015). }\end{array}$ & $\begin{array}{l}\text { Eva, ROI, Stock market's } \\
\text { value }\end{array}$ & $\begin{array}{l}\text { The return on investment (ROI) is better than (EVA) to interpret the } \\
\text { changes in Stock market's value, where the coefficient of determination } \\
\text { (R2) for the ROI is }(22.5 \%) \text {, while the R2 for EVA Only } 1.3 \% \text {. }\end{array}$ \\
\hline Hundal S., (2015), & $\begin{array}{l}\text { (EVA), the firm decision } \\
\text { making, performance, } \\
\text { various dynamics of } \\
\text { agency costs }\end{array}$ & $\begin{array}{l}\text { True profit does not arise merely by paying debt cost to firms' debt holders } \\
\text { but only when shareholders were also rewarded with a fair return on their } \\
\text { investment. The EVA raises the bar of corporate performance, which adds } \\
\text { value to the firm, and determines performance based executive pay; } \\
\text { consequently, mitigating agency costs. Nonetheless, several institutional } \\
\text { factors restrict applicability of the EVA }\end{array}$ \\
\hline $\begin{array}{l}\text { (Hassan, 2014), Pakistani } \\
\text { listed commercial banks }\end{array}$ & $\begin{array}{l}\text { EVA, MVA, ROE, Return } \\
\text { on capital employed, } \\
\text { price-to-earnings ratio, } \\
\text { market to book value }\end{array}$ & The result showed positive correlation of EVA with MVA \\
\hline (Sharma and Kumar, 2010) & EVA, & $\begin{array}{l}\text { The studies conducted in the developed countries have largely been found } \\
\text { to be supporting EVA though there are certain studies in these countries } \\
\text { too that consider conventional measures as better tools of corporate } \\
\text { Performance reporting. However, in developing economies less numbers of } \\
\text { studies are available supporting the empirical validity of the concept as a } \\
\text { corporate performance measurement tool. The concept of EVA has gained } \\
\text { significant attention in the advanced economies, but implementation issues } \\
\text { and its validity is under debate all over the world }\end{array}$ \\
\hline (Shil,2009) & EVA, & $\begin{array}{l}\text { As corporate house plans to move from traditional to value based } \\
\text { performance measures, EVA would yield good result and the paper may } \\
\text { become helpful to them to comprehend the methodology }\end{array}$ \\
\hline $\begin{array}{l}\text { (Anil and Kanwal, 2007), 'A } \\
\text { group' companies listed on the } \\
\text { Bombay Stock Exchange. }\end{array}$ & EVA, Stock Prices, MVA, & $\begin{array}{l}\text { EVA is the single most significant explanatory variable in explaining the } \\
\text { variation in the Market Value Added as it finds a better reflection in the } \\
\text { market value of the share. }\end{array}$ \\
\hline $\begin{array}{l}\text { (Worthington and West, 2004), } \\
\text { Australian companies over the } \\
\text { period 1992- } 1998\end{array}$ & $\begin{array}{l}\text { economic value-added, } \\
\text { stock returns, }\end{array}$ & $\begin{array}{l}\text { An analysis of the components of EVA confirms that the GAAP-related } \\
\text { adjustments most closely associated with EVA are significant at the margin } \\
\text { in explaining stock returns }\end{array}$ \\
\hline $\begin{array}{l}\text { (Chen and Dodd, 1997), U.S. } \\
\text { companies }\end{array}$ & $\begin{array}{l}\text { EVA, residual income, } \\
\text { accounting earnings, stock } \\
\text { return }\end{array}$ & $\begin{array}{l}\text { EVA is more powerful than traditional measures of accounting profit in } \\
\text { explaining stock return; however, accounting earnings are still of } \\
\text { significant incremental information value in addition to EVA, and not only } \\
\text { is EVA similar to residual income in concept, the two metrics are } \\
\text { empirically comparable. The implications of the findings for researchers } \\
\text { and practitioners are discussed. }\end{array}$ \\
\hline
\end{tabular}

\section{Methodology}

In this study, the researchers relied on the analytical method of deductive inference based on the published financial statements of the target companies during the period 2001-2015 to test the effect of the independent 
variables on the dependent variable and the explanatory capacity of the study model using the multiple regression model. The data were published in the annual reports of companies through the ASE as well as the previous literature on the subject of the study and the statistical publications issued by the Central Bank of Jordan. The researchers used financial analysis ratios and SPSS program for statistical analysis and hypothesis testing.

\subsection{Hypothesis:}

$\mathrm{H} 0^{1}$ : There is no a significant impact for general prices level on the economic value added in the Jordanian companies listed on Amman Stock Exchange for the period (2001-2015).

$\mathrm{H}^{2}$ : There is no a significant impact for the profits before interest and taxes on the economic value added in the Jordanian companies listed on Amman Stock Exchange for the period (2001-2015).

\subsection{Descriptive Model:}

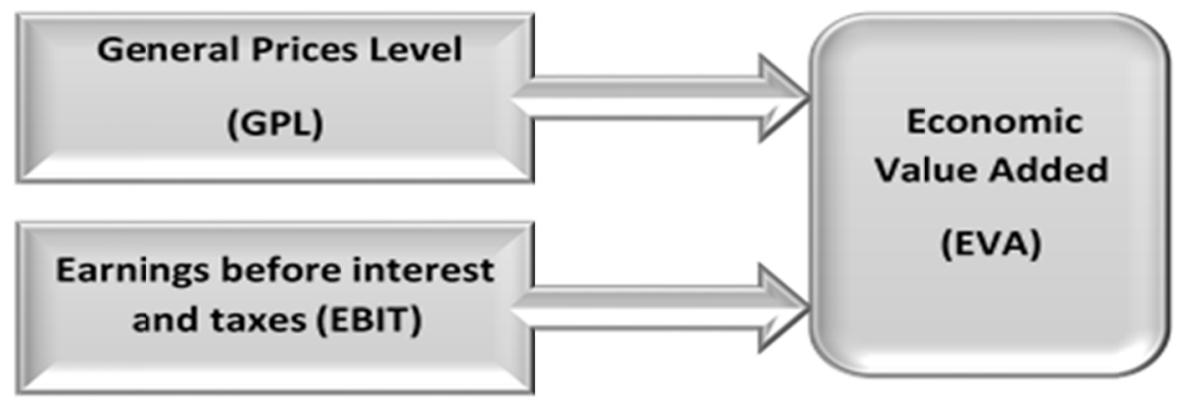

Figure 1. Descriptive model of the study variables

Source: prepared by the researchers, 2016

\subsection{Mathematical Model:}

The model used for such a study is a multiple regression model to clarify the effect of the independent variables on the dependent variable and the degree of the importance which is measured by calculating T-value, and the explanatory of the model.

The researchers used the following multiple regression model to measure the impact of independent variables on the dependent variable; equation number 7 (Shil, 2009)

$$
E V A=\alpha 0+B 1 * G P L+B 2 * E B I T+e i t
$$

Whereas:

EVA: Economic value Added.

GPL: General Prices Model.

EBIT: Earnings before interest and taxes.

\subsection{Society and Study Sample:}

The study was composed of all the public shareholding companies listed on the ASE during the period 2001-2015 which are almost 228 divided into 3 sectors: financial sector, industrial sector and service sector. Those were chosen from the Jordanian Public Shareholding Company's guide issued by the ASE (ASE, 2016), excluding the following companies:

1) Companies that merged with other companies during the study period.

2) Companies whose financial statements were not available during any one year of the study period.

3) Companies that did not continue to work during the study period and did not continue trading their shares during that period.

The valid society is (117) company out of (228) company, where the researcher excluded the companies that did not meet the criteria which are (111) company.

The sample of the study: 46 companies were selected by simple random way from the valid society which forms $40 \%$ of the valid society. Accordingly, the researcher completed the study. 


\subsection{Measures}

\subsubsection{The market value of the share (SMV).}

The researchers relied on closing prices from the ASE website, and then extracted the average market value of the shares of the companies surveyed during the whole study period.

\subsubsection{The economic value added (EVA).}

There are many ways to calculate EVA, but one of the main methods used to measure it, which was adopted for the purposes of the study, is the net operating profit after taxes (NOPAT) minus capital invested multiplied by Weighted Average Cost of Capital (WACC). The researcher calculated the EVA by equation number 8: (Ismail, 2011)

$$
E V A t=N O P A T-C t * W A C C
$$

Whereas :

EVAt: Economic Value Added

NOPAT: Net operating profit after tax.

Ct: Capital invested.

WACC: weighted average cost of capital.

The equation variables above were extracted by the researchers as follows:

NOPAT: net operating profit after tax and measures the generating capacity of cash flows from recurring operations and activities within the Company regardless of the capital structure, after deduction of taxes and before interest and depreciation and can be calculated according to equation number 9 (Hassan, 2014).

$$
\text { NOPAT }=\text { EBIT X }(1-\operatorname{tax})
$$

Whereas :

EBIT: Net profit before interest and tax rate of corporate income tax.

$\mathrm{Ct}$ : Capital invested, calculated by the total long-term liabilities and equity rights according to the equation number 10:

$$
C t=\text { Equity }+ \text { Long term debt }
$$

WACC: The weighted cost of the capital structure calculated according to equation number 11 (Al-Qudah \& Al-Afeef, 2015).

$$
W A C C=K d * W d *(1-T)+K s * W s
$$

Whereas:

$\mathrm{Kd}$ : The cost of the use of debt financing in the capital structure of the company, where the average interest rates issued by the Central Bank during the period of study was reached 0.089 .

Wd: Relative weight of the use of debt in the capital structure of the company.

$\mathrm{T}$ : Income tax rate on companies.

Ws: The relative weight of the use of equity in the capital structure of a company.

Ks: The cost of using proprietary finance in the capital structure of the company, and the Capital Asset Pricing Model (CAPM) was used to calculate the cost of financing the ownership represented by the required rate of return, as equation number 12: (Al-Qudah \& Al-Afeef, 2015)

$$
K s=R f+B j(R m-R f)
$$

Whereas:

Ks: The required yield on stocks which represents the cost of debt financing Kd.

Rf: Risk-free rate of return is usually calculated at the rate of return on government bonds issued by the central bank for a period of six months of 4.25\%. (Central Bank of Jordan, 2016)

Bj: Beta stock, which was calculated by the financial functions on the Excel software using the slope function of the returns of the stock and market returns. The annual returns of the shares and the market index were also calculated using Excel as equation number 13: (Al-Qudah \& Al-Afeef, 2015).

$$
K s=(P 1-P 0) / P 0
$$


Market return calculated by the Amman Stock Exchange general index.

\subsubsection{The rate of return on investment (ROI).}

The researchers used many methods in calculating the rate of return on investment, including the rate of return on assets and the rate of return on equity and return period of acquisition and other methods. In this study the rate of return on investment from (DuPont Analysis) was calculated by a composite percentage of the sales profitability ratio multiplied by the ratio of asset turnover rate as follows: (Al-Zubaidi, 2012).

Third: General Prices Level (GPL): Obtained from the publications of the Central Bank of Jordan for the study period.

Forth: Earnings before interest and taxes (EBI): calculated by equations no. (5.)

EBIT $=$ Revenue - Operating Expenses

The data were obtained from the ASE website.

\section{Statistical Analysis:}

After extracting the values of all the independent variables and the dependent variable; a model study using statistical analysis software (SPSS) was used to determine the impact of both (GPL) and (EBIT) on the market value added (EVA). The results were as follows:

Table 2. Descriptive Statistics

\begin{tabular}{lcccc}
\hline & EVA & Mean & Std. Deviation & N \\
& GPL & 1684194 & 3962210.010 & 180 \\
\multicolumn{1}{c}{ EBIT } & 61732.05 & 242285.97684 & 180 \\
\hline Table 3. Correlation & 7784885 & 2641924.274 & 180 \\
\hline \multicolumn{1}{r}{} & & & EBIT \\
\hline Pearson Correlation & EVA & EVA & GPL & -.302 \\
GPL & 1.000 & .366 & .014 \\
EBIT & .366 & 1.000 & 1.000 \\
Sig.(1-tailed) EVA & -.302 & .014 & .000 \\
GPL &. & .000 & .424 \\
EBIT & .000 &. &. \\
N EVA & .000 & .424 & 180 \\
GPL & 180 & 180 & 180 \\
EBIT & 180 & 180 & 180 \\
\hline
\end{tabular}

Table 3 shows the correlation between the study variables. The matrix of correlation was studied in order to make sure there's no relationship between each variables, which means that the results of the study model used by the researcher had no effect on the results, so the researcher continued the analysis process

Table 4. Model summary

\begin{tabular}{ccccccc}
\hline model & R & R Square & $\begin{array}{c}\text { Adjusted R } \\
\text { Square }\end{array}$ & $\begin{array}{c}\text { Std. Error of the } \\
\text { Estimate }\end{array}$ & $\begin{array}{c}\text { R Square } \\
\text { Change }\end{array}$ & Sig. \\
\hline $\mathbf{1}$ & $.478^{\mathrm{a}}$ & .229 & .220 & 3499343.773 & .229 & .000 \\
\hline
\end{tabular}

Predictors: (Constant), EBIT, GPL

Table 4 shows the explanatory power of the model through Adjusted R Square, which is about $22 \%$, this means that $22 \%$ of the changes in economic value added (EVA) due to the general level of prices and operating profit, and $78 \%$ of the changes due to other factors.

Table 5. ANOVA ${ }^{\mathrm{b}}$

\begin{tabular}{rllllll}
\hline model & & Sum Squares & df & Mean Square & F & Sig. \\
\hline $\mathbf{1}$ & Regression & $6.4 \mathrm{E}+014$ & 2 & $3.214 \mathrm{E}+014$ & 26.243 & $.000^{\mathrm{a}}$ \\
& Residual & $2.2 \mathrm{E}+015$ & 177 & $1.225 \mathrm{E}+013$ & & \\
& Total & $2.8 \mathrm{E}+015$ & 179 & & & \\
\hline
\end{tabular}

a. Predictors: (Constant), EBIT, GPL b. Dependent Variables: EVA 
Table 5 shows that the value of $F$ is (26.243) and the mean level of the study model is $(0.00)$ which is less than the value of the acceptable level of 0.05 , which means that the model was acceptable at a significant level $(0.01)$ and (0.05).

Table 6. Coefficients ${ }^{\mathrm{a}}$

\begin{tabular}{cllllll}
\hline Model & & B & Std. Error & Beta & T & Sig. \\
\hline 1 & (Constant) & 4900156 & 815543.5 & & 6.008 & .000 \\
& GPL & 6.063 & 1.080 & .371 & 5.615 & .000 \\
& EBIT & -.461 & .099 & -.308 & -4.658 & .000 \\
\hline
\end{tabular}

\section{a. Dependent Variable: EVA}

Table 6 shows the results of the T- test which shows the effect of the general level of prices and operating profit on economic value added.

$\mathrm{H}^{1}$ : There is no a significant impact for general prices level on the economic value added in the Jordanian companies listed on Amman Stock Exchange for the period (2001-2015).

Table 6 shows the result of the examination of this hypothesis. The above mentioned results indicate that the $\mathrm{P}$ value (Sig.) is (corresponding to 0.000 . This means that the Null hypothesis is rejected and the alternative hypothesis is accepted.

$\mathrm{H}^{2}$ : There is no a significant impact for the earnings before interest and taxes on the economic value added in the Jordanian companies listed on Amman Stock Exchange for the period (2001-2015).

Table 6 shows the result of the examination of this hypothesis. The above mentioned results indicate that the $\mathrm{P}$ value (Sig) is (corresponding to 0.000). This means that the Null hypothesis is rejected and the alternative hypothesis is accepted.

\section{Results}

1) There is a significant impact for general prices level on the economic value added in the Jordanian companies listed on Amman Stock Exchange for the period (2001-2015).

2) There is a significant impact for the earnings before interest and taxes on the economic value added in the Jordanian companies listed on Amman Stock Exchange for the period (2001-2015).

3) $22 \%$ of the changes in the economic value added are due to general prices level and earnings before interest and taxes, and $78 \%$ of the changes are due to other factors.

\section{Recommendations}

1) The researcher recommends public shareholding companies to seek the highest level of profits at the operational level and to develop operational processes and management of operating expenses because of the positive impact of operating profit on EVA value.

2) The researcher recommends to investors when calculating the value of EVA taking inflation into account because it is possible that the rise in EVA value is not real but because of the rise in the general level of prices.

3) Searching for other factors that could affect the value of EVA such as sales volume, cost of capital, and the growth in the total assets of the company's financial leverage, etc...

\section{References}

Al- Zubaidi, H. (2012). Financial analysis for the purposes of performance evaluation and prediction of failure (1st ed.). Alwarrak, Amman, Jordan.

Al-Afeef, M. (2017). The Impact of Economic Value Added \& Return on Investment on the Changes in Stock Market's Value (Analytical Study: ASE: 2006-2015). International Journal of Business and Management, 12(10), 132-142. https://doi.org/10.5539/ijbm.v12n10p132

Al-Qudah, A., Al-Afeef, M. (2015). Special topics in financial management (1st ed.). Lambert, Germany. https://www.lap-publishing.com/catalog/details//store/gb/book/978-3-659-82701-3/special-topics-in-financi al-management

Al-Sharqawi, A. (2006). The relationship between the economic value added and stock returns - process study, the fifteenth Annual Scientific Conference, Conference of financial markets and markets securities prospects and challenges, University of United Arab Emirates, UAE.

Amman Stock Exchange, http://www.ase.com.jo/ar 
Anil, M., \& Kanwal, A., (2007). Economic Value Added (EVA) as the most significant measure of financial performance: a study of select Indian firms. Journal of International Business and Economics, 7(1). http://www.freepatentsonline.com/article/Journal-International-BusinessEconomics/178900110.

Awan, A. G., Siddique, K., \& Sarwar, G. (2014). The effect of economic value added on stock return: evidence from selected companies of Karachi stock exchange. Research Journal of Finance and Accounting, 5(23), 140-52. Available online http://garj.org/garjmbs/index.htm

Central Bank of Jordan, http://www.cbj.gov.jo/

Chen, S. H., \& Dodd, J. (1997). Economic Value Added (EVA $\left.{ }^{\mathrm{TM}}\right)$ : An Empirical Examination of A New Corporate Performance Measure. Journal of Managerial, 9(3), 318-333.

Ehrbar, A. (1998). Stern Stewart's EVA: The real key to creating wealth (1st ed.). John Wiley \& Sons, New York, USA.

Falateh, A., \& Al-khayal, T. (2010). The relationship measurement between the economic value added and return on equity in the Saudi shareholding companies, Empirical Study. Journal of Accounting, administration and insurance, Faculty of Commerce, University of Cairo, 73(1), 633-636.

Hassan, N., Zohaib, M., Yaqub, M., \& Mehmood, B. (2014). Do Pakistani Banks Create Value?, Journal of Applied Environmental and Biological Sciences, 4(9S), 407-415.

$\mathrm{http} / /$ www.nasdaq.com/investing/glossary/g/general-price-level

Hundal, S., (2015). Economic Value Added (EVA), Agency Costs and Firm Performance: Theoretical Insights through the Value Based Management (VBM) Framework. Finnish Business Review, 1-16. http://urn.fi/urn:nbn:fi:jamk-issn-2341-9938-5

Ismail, I. (2011). The ability of EVA (Economic Value Added) attributes in Predicting company performance. African Journal of Business Management, 5(12), 4993-5000. DOI: 10.5897/AJBM11.118

Jiambalov, J. (2007). Managerial Accounting (3th ed.). Jhon wiley \& sons, Inc, New York.

McCulloch, J. H. (1982). Money and Inflation: A Monetarist Approach (2nd ed.). New York, Academic Press.

Mohammad, S. (2009). An Analytical Economic Study of Consumer Price Indices in Iraq for the Period 2000-2008. Iraqi Journal of Market Research and Consumer Protection, 1(2), 68-85.

Patell, J. M. (1978). Discussion of the impact of price-level adjustment in the context of risk assessment and the effect of general price-level adjustments on the predictive ability of financial ratios. Journal of Accounting Research (Studies on Changes in General and Specific Prices): 293-300. https://doi.org/10.2307/2490440

Sharma, A., \& Kumar, S. (2010). Economic Value Added (EVA) - Literature Review and Relevant Issues. International Journal of Economics and Finance, 2(2), 200-220. http://dx.doi.org/10.5539/ijef.v2n2p200

Shil, N. (2009). Performance Measures: An Application of Economic Value Added. International Journal of business and Management, 4(3), 169-177. https://doi.org/10.5539/ijbm.v4n3p169

Swaminathan, S., \& Weintrop, J. (1991). The Information Content of Earnings, Revenues, and Expenses. Journal of Accounting Research, 29(2), 418-427. https://doi.org/10.2307/2491058

Tippett, M., \& Whittington, G. (1988). General Price-level Adjustment: Some Properties of the Edwards and Bell Method. Journal of Accounting and Business Research, (19), 65-77. https://doi.org/10.1080/00014788.1988.9728837

Worthington, C. A., \& West, T., (2004). Australian Evidence Concerning the Information Content of Economic Value-Added. Australian Journal of Management 29(2), 201-224. https://doi.org/10.1177/031289620402900204

\section{Copyrights}

Copyright for this article is retained by the author(s), with first publication rights granted to the journal.

This is an open-access article distributed under the terms and conditions of the Creative Commons Attribution license (http://creativecommons.org/licenses/by/4.0/). 